\title{
Variation in the Maximum Number of Nucleoli in Diploid and Triploid Common Carp
}

\author{
Odang Carman, ${ }^{* 1}$ Takashi Oshiro, ${ }^{* 1}$ and Fumio Takashima ${ }^{* 1,2}$ \\ (Received June 8, 1992)
}

\begin{abstract}
The variation in the maximum number of nucleoli per cell in diploid and triploid common carp Cyprinus carpio related to their age was found in attempts to verify the validity of nucleoli counting as an indirect method for polyploidy identification in fish. Although in most cases diploid common carp have a maximum of two nucleoli per cell, some individuals with a maximum of either one, three, and four nucleoli per cell were observed. Anomaly in the silver-stained appearance and the maximum number and distribution of nucleoli were also found in the liver cells, but no clear difference in the maximum number or distribution was found in other somatic tissues (gill, intestine, kidney, spleen, or caudal fin) in either male or female. Most triploids, calibrated by chromosome counts, derived from breeders with a maximum of two nucleoli per cell, had a maximum of three nucleoli per cell. But the distribution of nucleoli in diploid and triploid individuals showed considerable variation, and the maximum number of nucleoti per cell of some triploids changed from two at 1 year to three at 3 years after hatching.
\end{abstract}

Polyploid fish are relatively easy to produce by preventing the extrusion of the second polar body or by blocking early cell divisions in the fertilized eggs using chemical or physical treatments. ${ }^{1-\tau)}$ However, a reliable method for rapid identification of polyploidy is still unavailable in many laboratories. There are some reports on a simple method ${ }^{8-13)}$ of fish chromosome preparation which is notably advanced in the identification of ploidy levels. It is still believed that this kind of method is time-consuming and impractical for field work. In our laboratory, some efforts have been made to solve these problems, based on biological, biochemical, and genetic approaches that lead to observations of characteristics that express ploidy level.

Nucleoli counting is an indirect method for identification of polyploidy. ${ }^{14}$ ) The number of nucleoli may greatly increase under some physiological conditions (e.g. in growing oocytes) without a corresponding increase in chromosome sets. But in somatic interphase cells, there is a close relationship between the number of visible nucleoli and the number of chromosome sets. ${ }^{15}$ Since the cells of any given species of plant or animal usually have a fixed number of nucleoli, ${ }^{10}$ ) the ploidy level of any species can be estimated easily by counting the number of nucleoli.
The relation between the number of nucleoli and the number of chromosome sets in plants and animals has been known for five decades ${ }^{15}$ ) and had been used for polyploidy identification in fish. ${ }^{17,18)}$ Visualization of nucleoli using silver staining is very simple and practical; the method involves silver staining cells and determining the maximum number of nucleoli per cell. ${ }^{18,10)}$ In routine work, this indirect method has the potential for rapid identification of ploidy levels. Nevertheless, our observations over the past few years with several types of freshwater fish have shown some exceptions. These led us to pose some questions on the reliability of this procedure and to search for the possibility of improving the methodology.

In this study, we examined the nucleoli number and its variation in various tissues of common carp (caudal fin, gill, liver, kidney, spleen, and intestine) and those of caudal fins at different ages, sexes, and ploidy level.

\section{Materials and Methods}

Common carp Cyprinus carpio at different ages cultivated for several generations at Yoshida Experimental Station at the Tokyo University of Fisheries were used as some of the experimental

*1 Department of Aquatic Biosciences, Tokyo University of Fisheries, Konan, Minato, Tokyo 108, Japan (O. Carman, 尾城 鲉, 隆島史夫; 東京水産大学资源育成学科).

*2 To whom correspondence should be addressed. 
fish. A triploid and diploid mixture group was produced by cold-shocking the eggs at $4^{\circ} \mathrm{C}$ for $30 \mathrm{~min}, 6 \mathrm{~min}$ after insemination.

A small piece of caudal fin was cut and removed from live fish, and used as a tissue source for confirming the nucleoli number per cell at different ages (i.e. $0,1,2,4$, and 6 years old), sexes, and ploidy levels. For examination of the nucleoli number per cell in different tissues, 7 fish from the 2-year-old group were killed and parts of their caudal fins, gills, livers, kidneys, spleens, and intestines were removed.

All tissues were fixed at about $4^{\circ} \mathrm{C}$ in two changes of Carnoy's solution (1:3 acetic acid: ethanol) for at least $30 \mathrm{~min}$ each, and then processed or stored in a refrigerator for several weeks. The tissue was dispersed in $50 \%$ acetic acid on a watch glass. Using a micropipette tip, the resulting cell suspension was expelled onto an alcoholcleaned slide glass placed on a slide warmer (45$55^{\circ} \mathrm{C}$ ). The suspension was quickly withdrawn back into the micropipette tip leaving a ring of cells approximately $1-1.5 \mathrm{~cm}$ in diameter on the slide glass. Slides were then silver stained according to Howell and Black ${ }^{18)}$ with some modifications and observed under the microscope.

Mixed triploids and diploids were individually distinguished using electronic tags (Identification Devices Inc.) and nucleoli numbers per cell were checked for 1- and 3-year-olds by the method mentioned above. Chromosome preparations were made from blood culture ${ }^{20}$ and stained in $10 \%$ Giemsa solution for $20 \mathrm{~min}$. Well-spread metaphases were counted using camera lucida.

\section{Results and Discussion}

We observed more than 80 normal diploid individuals comprising five different age groups, and found that most of them possessed two nucleoli as the maximum number per cell: one nucleolus in about half the number of cells, and two nucleoli in the remainder. However, even at low percentages, individuals with a maximum of either one or four nucleoli, and a considerable number of individuals with a maximum of three nucleoli were observed. Next, we chose individuals which had the maximum of two nucleoli per cell as experimental fish to observe tissue and sex differences as well as for breeders to produce triploids. The maximum number and distribution of nucleoli in the cells at different ages, tissues, sexes, and ploidy levels are summarized in Tables $1,2,3$, and 4, respectively. Nucleoli of interphase cells appear as distinct black bodies varying in size within the yellowish orange nuclei. Silverstained cells from different tissues are shown in Figs. $1 \mathrm{~A}-\mathrm{H}$ and $2 \mathrm{~A}-\mathrm{B}$.

All individuals observed in the 0-year-old group possess a maximum of two nucleoli per cell. The 1-year-old and 2-year-old groups each contained an individual with only one nucleolus per cell. In addition, one individual in the 4-year-old group had a maximum of four nucleoli per cell. Individuals having a maximum of three nucleoli per cell were observed to occur more frequently as their age increased, i.e. 10, 41, and $53 \%$ in 2-, 4-, and 6-year-old groups, respectively. Considering that there was variation

Table 1. Maximum number and frequency distribution of nucleoli per cell in normal diploid common carp at different ages

\begin{tabular}{|c|c|c|c|c|c|c|c|c|c|c|}
\hline \multirow{2}{*}{$\begin{array}{l}\text { Fish } \\
\text { age }\end{array}$} & \multirow{2}{*}{$\begin{array}{l}\text { Sampled } \\
\text { fish }\end{array}$} & \multirow{2}{*}{$\begin{array}{c}\text { Indi- } \\
\text { vidual } \\
\text { number }\end{array}$} & \multicolumn{4}{|c|}{$\begin{array}{l}\text { Maximum number } \\
\text { of nucleoli per cell }\end{array}$} & \multicolumn{4}{|c|}{ Distribution of nucleoli number per cell $(\%)^{*}$} \\
\hline & & & 1 & 2 & 3 & 4 & 1 & 2 & 3 & 4 \\
\hline $0+$ & 9 & 9 & & - & & & $34-76(53.3)$ & $25-66(46.7)$ & & \\
\hline \multirow{2}{*}{$1+$} & 11 & 1 & 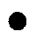 & & & & $(100)$ & & & \\
\hline & & 10 & & $\bullet$ & & & $35-49(41.0)$ & $51-65(59.0)$ & & \\
\hline \multirow[t]{3}{*}{$2+$} & 20 & 1 & $\bullet$ & & & & $(100)$ & & & \\
\hline & & 17 & & - & & & $34-72(49.0)$ & $28-66(51.0)$ & & \\
\hline & & 2 & & & - & & $30-51(40.3)$ & $45-50(47.4)$ & $4-20(12.3)$ & \\
\hline \multirow[t]{3}{*}{$4+$} & 22 & 12 & & - & & & $36-92(48.7)$ & $8-64(51.3)$ & & \\
\hline & & 9 & & & - & & $18-62(41.0)$ & $37-57(46.6)$ & $2-31(12.4)$ & \\
\hline & & 1 & & & & $\bullet$ & $(19.5)$ & $(41.9)$ & $(26.7)$ & $(11.9)$ \\
\hline \multirow[t]{2}{*}{$6+$} & 15 & 7 & & 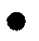 & & & $45-56(52.7)$ & $44-55(47.3)$ & & \\
\hline & & 8 & & & - & & $20-41(31.1)$ & $49-59(53.8)$ & $9-21(15.0)$ & \\
\hline
\end{tabular}

* Nucleoli of $200-230$ cells were counted in each individual. 
Table 2. Maximum number and frequency distribution of nucleoli per cell in various somatic tissues of 2-year-old normal diploid common carp having maximally 2 nucleoli per cell

\begin{tabular}{|c|c|c|c|c|c|}
\hline \multirow{2}{*}{$\begin{array}{l}\text { Kind of } \\
\text { tissue }\end{array}$} & \multirow{2}{*}{$\begin{array}{c}\text { Individual } \\
\text { number }\end{array}$} & \multicolumn{2}{|c|}{$\begin{array}{l}\text { Maximum number } \\
\text { of nucleoli per cell }\end{array}$} & \multicolumn{2}{|c|}{$\begin{array}{l}\text { Distribution of } \\
\text { nucleoli number per cell }(\%)^{*}\end{array}$} \\
\hline & & 1 & 2 & 1 & 2 \\
\hline Caudal fin & 7 & \multirow{4}{*}{ - } & - & $46-57(50.0)$ & $43-54(50.0)$ \\
\hline Gill & 7 & & - & $38-58(46.4)$ & $42-57(53.6)$ \\
\hline \multirow[t]{2}{*}{ Liver } & 1 & & & $(100)$ & \\
\hline & 6 & & $\bullet$ & $92-98(94.8)$ & $5-11(5.2)$ \\
\hline Intestine & 7 & & - & $51-70(58.6)$ & $31-49(41.4)$ \\
\hline Kidney & 7 & & - & $42-53(47.6)$ & $47-59(52.4)$ \\
\hline Spleen & 7 & & - & $56-66(600)$ & $34-44(40.0)$ \\
\hline
\end{tabular}

Table 3. Maximum number and frequency distribution of nucleoli per cell in caudal fin of both sexes of 2-year-old normal diploid common carp

\begin{tabular}{|c|c|c|c|c|c|c|c|}
\hline \multirow[t]{2}{*}{ Sex } & \multirow{2}{*}{$\begin{array}{l}\text { Individual } \\
\text { number }\end{array}$} & \multicolumn{3}{|c|}{$\begin{array}{l}\text { Maximum number } \\
\text { of nucleoli per cell }\end{array}$} & \multicolumn{3}{|c|}{$\begin{array}{c}\text { Distribution of } \\
\text { nucleoli number per cell }(\%)\end{array}$} \\
\hline & & 1 & 2 & 3 & 1 & 2 & 3 \\
\hline 우 & 7 & & - & & $44-72(53.9)$ & $28-56(46.1)$ & \\
\hline$\theta^{*}$ & 6 & & - & & $34-57(45.2)$ & $43-66(54,8)$ & \\
\hline
\end{tabular}

* Nucleoli of 200-230 cells were counted in each individual.

Table 4. Maximum number and frequency distribution of nucleoli per cell in caudal fin of 1and 3-year-old normal diploid and triploid common carp

\begin{tabular}{|c|c|c|c|c|c|c|c|c|c|c|}
\hline \multirow{2}{*}{$\begin{array}{l}\text { No. } \\
\text { of } \\
\text { fish }\end{array}$} & \multirow{2}{*}{$\begin{array}{c}\text { No. } \\
\text { of } \\
\text { tag }\end{array}$} & \multirow{2}{*}{ Ploidy* } & \multicolumn{4}{|c|}{$\begin{array}{l}\text { Distribution of nucleoli number } \\
\text { per cell at } 1 \text { year old }(\%)\end{array}$} & \multicolumn{4}{|c|}{$\begin{array}{l}\text { Distribution of nucleoli number } \\
\text { per cell at } 3 \text { year old }(\%)\end{array}$} \\
\hline & & & Max. & 1 & 2 & 3 & Max. & 1 & 2 & 3 \\
\hline 1 & $44262 \mathrm{~A}$ & $3 \mathrm{~N}$ & 3 & $128(40.51)$ & $147(46.52)$ & $41(1297)$ & 3 & $116(35.15)$ & $169(51.21)$ & $45(13.64)$ \\
\hline 2 & $441 \mathrm{C} 00$ & $3 \mathrm{~N}$ & 3 & $110(4392)$ & $168(53.33)$ & $37(11.75)$ & 3 & $103(28.77)$ & $192(53.63)$ & $63(17.60)$ \\
\hline 3 & $43043 \mathrm{~A}$ & $3 \mathrm{~N}$ & 3 & $170(4545)$ & $186(49.73)$ & $18(4.81)$ & 3 & $124(37.92)$ & $178(54.43)$ & $25(7.65)$ \\
\hline 4 & $43027 \mathrm{E}$ & $2 \mathrm{~N}$ & 2 & $183(57.37)$ & $136(42.63)$ & & 2 & $154(44.90)$ & $189(55.10)$ & \\
\hline 5 & 442836 & $3 N$ & 3 & $79(24.46)$ & $152(47.06)$ & $92(28.48)$ & 3 & $68(19.05)$ & $166(46.50)$ & $123(34.45)$ \\
\hline 6 & $441 \mathrm{D} 5 \mathrm{~B}$ & $3 \mathbf{N}$ & 2 & $120(38.83)$ & $189(61.17)$ & & 3 & $120(44.44)$ & $149(55.19)$ & $1(0.37)$ \\
\hline 7 & 443431 & $3 N$ & 3 & $106(33.87)$ & $144\left(\begin{array}{ll}46 & 01)\end{array}\right)$ & $63(20.13)$ & 3 & $75(24.27)$ & $162(52.43)$ & $72(23.30)$ \\
\hline 8 & 443121 & $3 N$ & 3 & $103(38.15)$ & $131(48.52)$ & $36(13.33)$ & 3 & $56(17.72)$ & $157(49.68)$ & $103(32.59)$ \\
\hline 9 & 442255 & $2 \mathrm{~N}$ & 2 & $274(7632)$ & $85(23,68)$ & & 2 & $236(75.88)$ & $75(24.12)$ & \\
\hline 10 & $43065 \mathrm{~F}$ & $3 \mathrm{~N}$ & 3 & $70(22.22)$ & $160(50.79)$ & $85(26.98)$ & 3 & $58(16.67)$ & $180(51.72)$ & $110(31.61)$ \\
\hline 11 & $425 \mathrm{~F} 16$ & $3 N$ & 2 & $140(4620)$ & $163(53.80)$ & & 3 & $123(39.42)$ & $181(58.01)$ & $8(2.56)$ \\
\hline 12 & $431 \mathrm{C} 7 \mathrm{~A}$ & $3 \mathrm{~N}$ & 3 & $74(2209)$ & $163(48,66)$ & $98(29.25)$ & 3 & $63(18.58)$ & $153(45.13)$ & $123(36.28)$ \\
\hline 13 & 430632 & $3 N$ & 2 & $148\left(\begin{array}{ll}49 & 01\end{array}\right)$ & $154\left(\begin{array}{ll}50 & 99\end{array}\right)$ & & 3 & $107(3302)$ & $207(63.89)$ & $10(3.09)$ \\
\hline 14 & $3 \mathrm{D} 380 \mathrm{E}$ & $2 \mathrm{~N}$ & 2 & $168(5472)$ & $139(45,28)$ & & 2 & $181(5231)$ & $165(47.69)$ & \\
\hline 15 & $441 E 3 D$ & $3 N$ & 3 & $97(28.61)$ & $156(46.02)$ & $86\left(\begin{array}{ll}25 & 37\end{array}\right)$ & 3 & $79(2358)$ & $174(51.94)$ & $82(2448)$ \\
\hline 16 & $3 F 6536$ & $3 N$ & 3 & $94(31.02)$ & $139(54 \quad 87)$ & $70\left(\begin{array}{ll}23 & 10\end{array}\right)$ & 3 & $75\left(\begin{array}{ll}19 & 48\end{array}\right)$ & $190(49.35)$ & $120(31 \quad 17)$ \\
\hline
\end{tabular}

in the maximum number of nucleoli per cell and the percentage of individuals having the maximum number of two nucleoli per cell was highest in all age groups, we believe that normal diploid common carp has the maximum number of more than two nucleoli per cell, but that in most cases only two nucleoli are visible when stained with silver nitrate. Variation occurring on the maximum number was probably the result of fusion and fission to form single and three nucleoli, respective- 


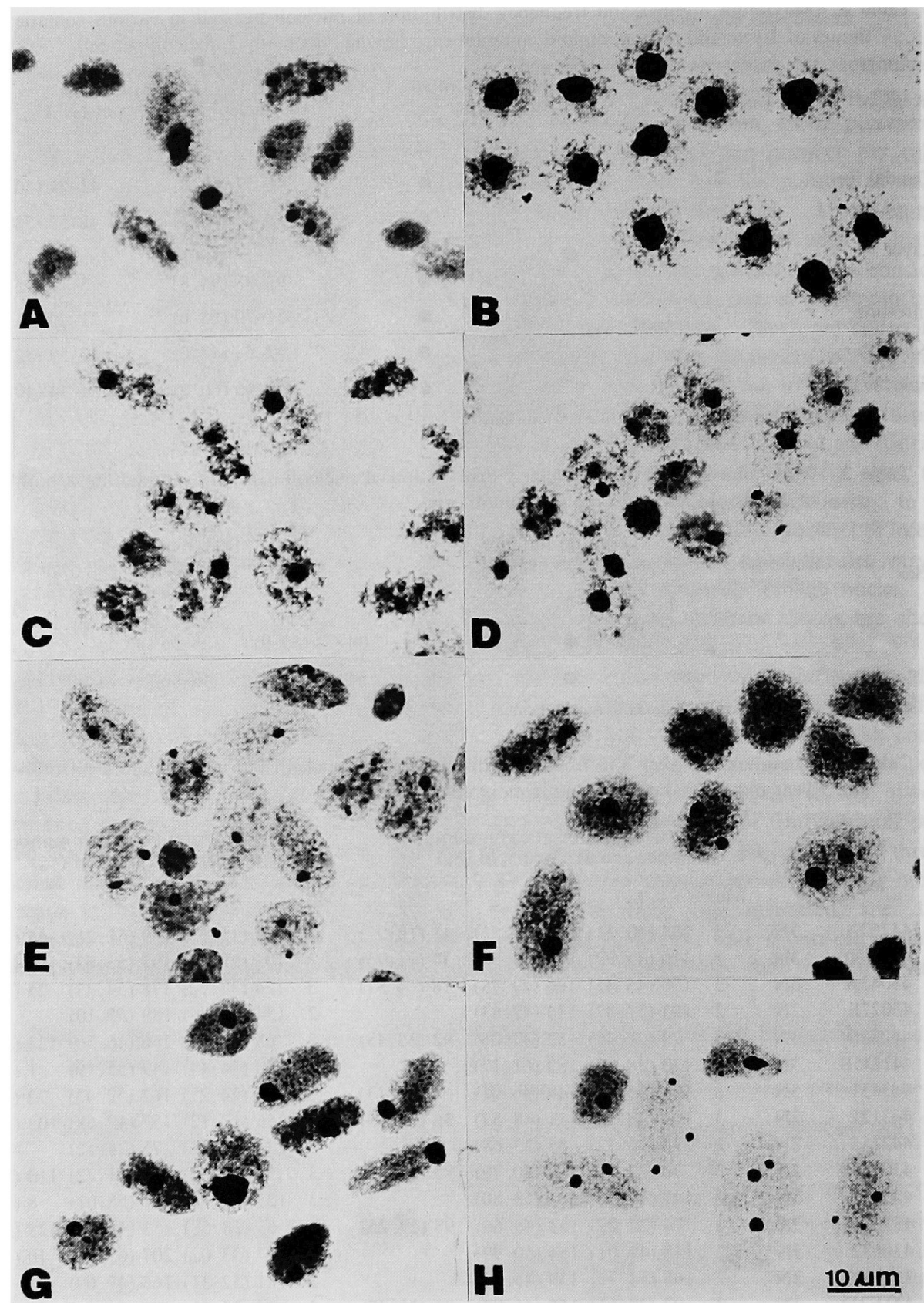

Fig. 1. Silver-stained interphase cells of a diploid common carp; gill (A), liver (B), intestine (C), kidney (D), spleen (E), and caudal fins from different diploid carp with a maximum number of two $(\mathrm{F})$, one $(\mathrm{G})$, and three $(\mathrm{H})$ nucleoli.

ly, because of some physiological processes during the cell cycle. When special attention was paid to the performance of silver-stained nucleoli, the nucleoli size in cells with a lower maximum number was bigger than that in the cells with a higher maximum number (Figs. 1 F$\mathrm{H}$ and $2 \mathrm{~A}$ ). Nucleoli fusion has been known in human diploid cells ${ }^{21}$ ) which actually have 10 nucleoli formed after mitosis (10 NORs in 10 of the 46 chromosomes), gradually decrease in 

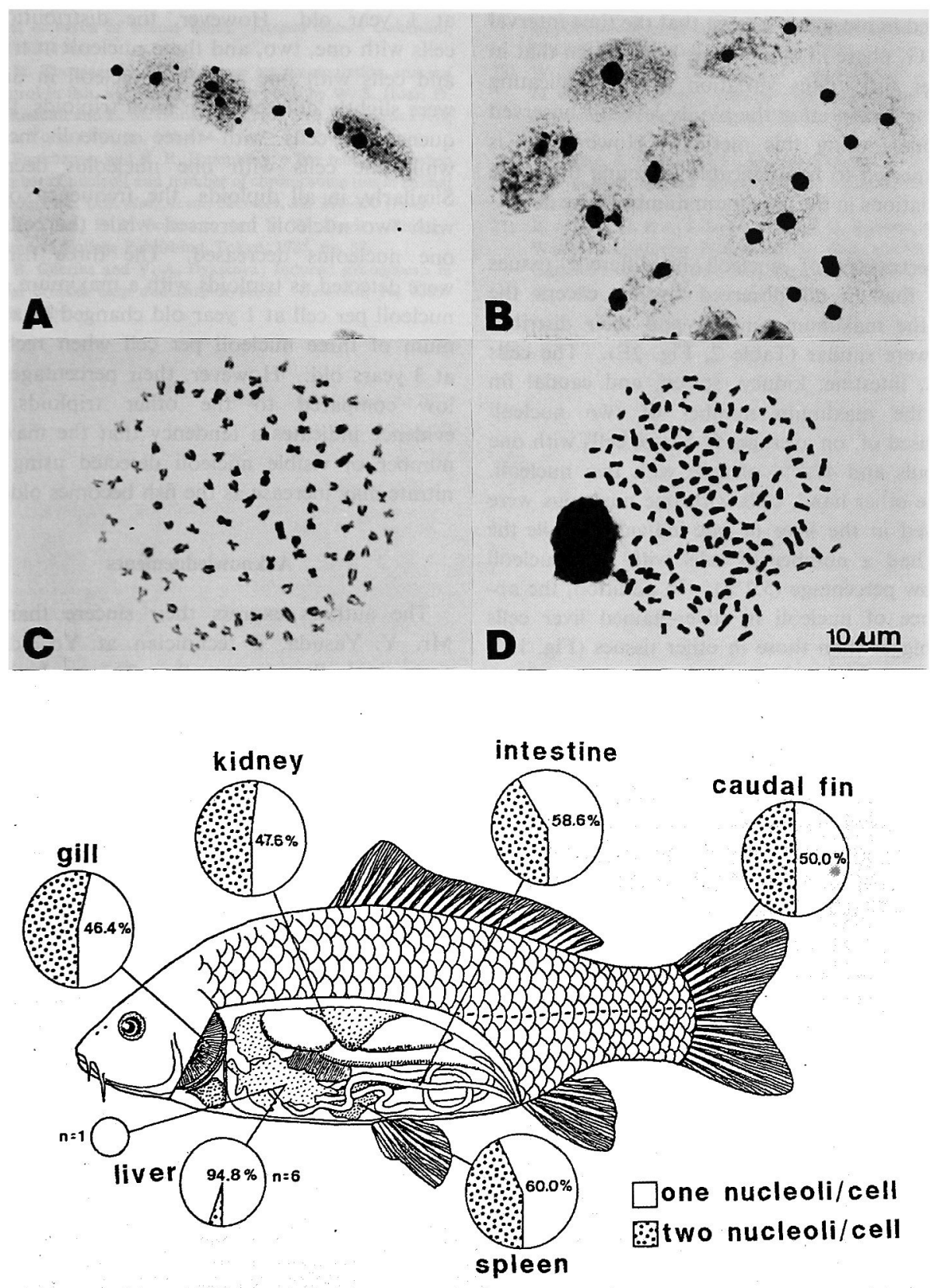

E

Fig. 2. Silver-stained interphase cells of common carp diploid with the maximum of four nucleoli (A) and triploid with a maximum of three nucleoli (B), chromosome preparations of diploid, $2 n=100$ (C) and triploid, $3 n=150$ (D) and distribution of nucleoli in various somatic tissues of 2-year-old diploid common carp (E).

number and increase in size during the first half of the $G_{1}$ phase (the interval between the end of mitosis ( $M$ phase) and the beginning of DNA synthesis (S phase) in the cell cycle) but they quickly grow and fuse to form the single large nucleolus commonly visible in many interphase cells rather than appearing as separate entities. The variations on the maximum number which 
occurred in older fish suggest that the time interval of the $G_{1}$ phase in older fish is longer than that in younger fish. This variation is a complicating factor in interpreting the ploidy level of boserved individuals using this method. However, it is still expected to be applicable in young fish since no variations in the maximum number were detected.

Observations of nucleoli in different tissues reveal that in all observed tissues, except the liver, the maximum number and their distributions were similar (Table 2, Fig. 2E). The cells of gill, intestine, kidney, spleen, and caudal fin have the maximum number of two nucleoli comprised of, on average, $52.5 \%$ of cells with one nucleouls and $47.5 \%$ of cells with two nucleoli. On the other hand, cells with one nucleolus were observed in the liver of one individual while the other had a number of cells with two nucleoli at a low percentage $(5.2 \%)$. In addition, the appearance of nucleoli in silver-stained liver cells were bigger than those in other tissues (Fig. 1B). This probably reflects high ribosomal RNA (rRNA) synthesis which occurs inside the nuclei. These results indicated that selection of tissue source should be considered when trying to check ploidy levels using this method. Except the liver, all other tissues observed in this study can be used as a tissue source but we suggest the use of the caudal fin where the tissue can be collected without killing the fish.

As shown in Table 3, no clear difference was found in the distribution of nucleoli between male and female; on average, the percentage of cells with two nucleoli in the male was slightly lower $(45.2 \%)$ than that in the female $(53.9 \%)$.

Triploidy was successfully induced at a rate of $83 \%$. Diploids and triploids possessed chromosome numbers 100 and 150 , respectively (Figs. 2C and 2D). The maximum number and distribution of nucleoli in diploids and triploids at 1 and 3 years old are shown in Table 4 . The results of examination conducted on 1-year-old fish indicated that diploids had a maximum of two nucleoli per cell. No diploids with a maximum of either one, three, or four nucleoli per cell were observed. On the other hand, 10 fish of 13 triploids had a maximum of three nucleoli per cell while the other 3 fish showed a maximum of two nucleoli per cell (see Table 4). Reexamination of the same group undertaken on 3-yearold fish showed that most of the individuals had the same maximum number of nucleoli as detected at 1 year old. However, the distributions of cells with one, two, and three nucleoli in triploids and cells with one and two nucleoli in diploids were slightly different. In most triploids, the frequency of cells with three nucleoli increased while the cells with one nucleolus decreased. Similarly, in all diploids, the frequency of cells with two nucleoli increased while the cells with one nucleolus decreased. The three fish that were detected as triploids with a maximum of two nucleoli per cell at 1 year old changed to a maximum of three nucleoli per cell when rechecked at 3 years old. However, their percentages were low compared to the other triploids. This evidence indicates a tendency that the maximum number of visible nucleoli detected using silver nitrate may increase as the fish becomes older.

\section{Acknowledgements}

The authors express their sincere thanks to Mr. Y. Yasuda, a technician at Yoshida Experimental Station at the Tokyo University of Fisheries, for his help in fish rearing, and Mr. N. B. Choon who produced triploid fish.

\section{References}

1) T, Refstie, V. Vassvik, and T. Gjedrem: Induction of polyploidy in salmonids by cytochalasin B. Aquaculture, 10 . 65-74 (1977).

2) J. G. Stanley, S. K. Allen Jr., and H. Hidu: Polyploidy induced in the American oyster, Crassostrea virginica, with cytochalasin B. Aquaculture, 23, 1-10 (1981).

3) C. E. Purdom: Induced polyploidy in plaice (Pleuronectes platessa) and its hybrid with the flounder (Platichthys flesus). Heredity, 29, 11-24 (1972).

4) R. J. Valenti: Induced polyploidy in Tilapia aurea by means of temperature shock treatment. J. Fish Biol., 7, 519-528 (1975).

5) H. L. Lemoine, Jr. and L. T. Smith; Polyploidy induced in brook trout by cold shock. Trams. Am. Fish. Soc., 109, 626631 (1980).

6) K. Arai, F. Naito, and K. Fujino: Triploidization of the Pacific abalone with temperature and pressure treatments. Nippon Suisan Gakkaishi, 52, 417-422 (1986).

7) T. J. Benfey and A. M. Sutterlin: Triploidy induced by heat shock and hydrostatic pressure in Landlocked Atlantic salmon Salmo salar L.). Aquaculture, 36, 359-367 (1984).

8) P. C. Blaxhall: Fish chromosome techniques: a review of selected literature. J. Fish. Biol, 7, 315-320 (1975).

9) J. D. McPhail and R. L. Jones: A simple technique for obtaining chromosomes from teleost fishes. J. Fish. Res. Board Can., 23, 767-769 (1966).

10) F. L. Roberts: Chromosome cytology of the osteichthyes. Prog. Fish Cutt., 29, 75-83 (1967).

11) J. R. Gold: A fast and easy method for chromosome karyotyping in adult teleosts. Prog. Fish Cult., 36, 169-171 (1974).

12) A. D. Kligerman and S. E. Bloom: Rapid chromosome preparations from solid tissues of fishes. J. Fish. Res. Board Can., 34, 266-269 (1977).

13) F. Yamazaki, H. Onozato, and K. Arai: The chopping 
method for obtaining permanent chromosome preparation from embryos of teleost fishes. Nippon Suisan Gakkaishi, 47, 963 (1981).

14) G. H. Thorgaard: Chromosome set manipulation and sex control in fish, in "Fish Physiology" (ed. by W. S. Hoar, D. J., Randall and E. M. Donaldson), Vol. IXB, Academic Press, New York, 1983, pp. $40 S-434$.

15) G. Fankhauser and R. R. Humphrey: The relation between number of nucleoli and number of chromosome sets in anima! cells. Proc. U.S. Nat. Acad., Sciences, 29, 344-350 (1943).

16 C. A. Villee, E. P. Solomon, and P. W. Davis: Biology, Sounders College Publishing, Tokyo, 1985, pp. 89.

17) N. B. Cherfas and V. A. Ilyassova: Induced gynogenesis in silver crucian carp and carp hybrids. Genetika, 16, 12601269 (1980).
18) R. B. Phillips, K. D. Zajicek, P. E. Ihssen, and O. Johnson: Application of silver staining to the identification of triploid fish cells. Aquaculture, 54, 313-319 (1986).

19) W. M. Howell and D. A. Black: Controlled silver-staining of nucleolus organizer regions with a protective colloidal developer: a 1-step method. Experientia, 36, 1014-1015 (1980).

20) Y. Ojima, S. Hitotsumachi, and M. Hayashi: A blood culture method for fish chromosomes. Japan J. Genet.s 45 , 161-162 (1970).

21) B. Alberts, D. Bray, J. Lewis, M. Raff, K. Roberts, and J. D. Watson: Molecular Biology of the Cell, second edition, Garland Publishing, Inc., New York and London, 1989, pp. $481-549$. 